\title{
INOVASI MANAJEMEN PENGELOLAAN SAMPAH YANG BERWAWASAN LINGKUNGAN DI KOTA PONTIANAK BERBASIS APLIKASI
}

\author{
Ul Qadri $^{1)}$, Riska Wahyuni ${ }^{2)}$, \& Lilis Listiyawati ${ }^{3)}$ \\ 1, 2, 3 Jurusan Akuntansi, Politeknik Negeri Pontianak \\ email: akhiulqadri@gmail.com
}

\begin{abstract}
Waste management is problems are almost faced by all cities in Indonesia. Therefore, it is necessary to manage waste management with environmentally sound management in accordance with the mandate of Law No. 18 of 2008 on waste management. The aspect highlighted in the management of waste management in Pontianak City is the technical aspect of waste management and non-technical operations so that it can be known whether management of waste management is environmentally sound or unlike the bill of legislation. Pontianak City makes application-based innovations in managing garbage. The purpose of this research is to describe, analyse, and interpret, as well as recommendations on: (1) Waste management management covering technical aspects of operational and nontechnical. (2) Environmentally sound and application-based waste management management. The methods used are qualitative descriptive, approach study studies, data sources derived from interviews with informant, observation and documentation. The data analysis technique used is interactive model analysis by reducing data, presenting data, drawing conclusions and verification.
\end{abstract}

Keywords: Innovation, Waste, Application, Pontianak

\section{PENDAHULUAN}

Lingkungan dan manusia dalam kehidupan merupakan satu kesatuan yang tidak dapat dipisahkan dan saling terkait antar satu dengan lainnya. Manusia membutuhkan kondisi lingkungan yang baik agar dapat melaksanakan aktivitasnya, sebaliknya kondisi lingkungan yang baik tergantung pada aktivitas manusia terhadap lingkungan (Prasetyo, Indriani, \& Widodo, 2020). Daerah Perkotaan sebagai pusat aktivitas telah berkembang dengan pesat dan berperan sebagai pusat pemerintahan, perdagangan, kebudayaan, pariwisata, transportasi maupun industri.

Perkembangan dunia industri dan pertambahan jumlah penduduk yang semakin meningkat dari tahun ke tahun, meningkatnya sampah industri dan sampah domestik yang dihasilkan oleh penduduk sehingga semakin membebani tanah, udara dan sungai yang mengalir dalam wilayah perkotaan. Akibat pertambahan jumlah penduduk yang setiap tahunnya mengalami peningkatan, jarang sekali dalam suatu wilayah kota di temukan ruang terbuka yang dapat digunakan untuk daerah pemukiman yang layak.

Ini disebabkan karena ruang terbuka tersebut berubah fungsi menjadi tempat pembuangan berbagai macam sampah dari hasil aktivitas manusia,berupa sampah dari kegiatan rumah tangga, perkantoran, lembaga (instansi), pasar, terminal, restoran serta industri. Secara garis besar, sampah perkotaan berasal dari pencemaran yang disebabkan oleh industri 
dan sektor domestik yang menghasilkan limbah domestik (sampah domestik).

Sampah domestik ini terdiri dari sampah organik dan sampah non organik. Sampah organik berasal dari mahluk hidup yang dapat terdegradasi sedangkan sampah non organik yang tidak dapat terdegradasi misalnya: plastik, kaleng, kaca, dan lain-lain. Selain sampah organik dan sampah non organik terdapat juga sampah berbahaya, contohnya: jarum suntik, baterai, dan lain-lain. Sementara sampah industri terdiri dari emisi dari proses pembakaran, limbah cair (sampah cair), limbah padat (sampah padat). Volume sampah dan jenis yang dihasilkan tergantung dari pola komsumsi suatu masyarakat dalam suatu wilayah. Semakin tinggi tingkat pendapatan masyarakat tersebut maka semakin tinggi pula volume sampah yang dihasilkan dan semakin banyak jenis sampah yang dihasilkan. Tetapi pada umumnya sebagian besar sampah yang di hasilkan adalah jenis sampah organik (sampah basah), yaitu mencakup 60-70 \% dari total volume sampah (Kementerian Lingkungan Hidup, 2008).

Pengelolahan persampahan di perkotaan merupakan suatu sistem yang saling berinteraksi membentuk kesatuan dan mempunyai tujuan. Pengolahan sampah suatu kota bertujuan untuk melayani penduduk terhadap sampah domestik rumah tangga yang dihasilkannya secara tidak langsung memelihara kesehatan masyarakat serta menciptakan suatu lingkungan yang baik, bersih dan sehat. Sampah padat dari pemukiman merupakan bagian terbesar dari sampah yang timbul di Indonesia. Pemerintah bertanggung jawab dalam pemgumpulan ulang dan pembuangan sampah dari pemukiman secara memadai.

Namun karena terdapat hal lain yang harus diprioritaskan dalam pembangunan di daerah serta kurangnya dana penunjang untuk operasionalisasi pengolahan persampahan,menjadikan pada beberapa daerah kegiatan pengolahan sampah ini tidak seperti yang diharapkan. Hal ini makin diperkuat dengan belum diterapkannya prinsip bahwa yang memproduksi barang harus mengelola sampah dari barang tersebut.

Pada sisi lain sampah yang berasal dari pemukiman, pasar, taman, dan lain-lain, jika tidak dikelola secara baik, keberadaannya sering menimbulkan masalah bagi lingkungan, seperti:

1. Sampah yang tidak teratasi dengan baik dapat menyebabkan lingkungan tidak baik secara estetika.

2. Sampah yang membusuk menghasilkan gas yang berbau yang tidak sedap dan berbahaya bagi kesehatan, air yang dikeluarkan (leachate) juga dapat menyebabkan pencemaran sungai, maupun air tanah.

3. Sampah yang tercecer tidak pada tempatnya dapat menyebabkan tersumbatnya saluran drainase sehingga dapat menimbulkan banjir.

4. Kawasan yang padat penduduknya seperti kota besar akan kesulitan mencari lahan baru untuk Tempat Pembuangan Akhir (TPA).

Bagi negara berkembang pada umumnya menyelesaikan masalah sampah yaitu dengan membuang ke tempat lain, tentu saja ini bukan merupakan pemecahan masalah. Oleh sebab itu untuk meminimalisasi (pengurangan) sampah mencakup tiga usaha dasar yang dikenal dengan 3R, yaitu: Reduse (mengurangi): sebisa mungkin mengurangi barang dan material yang dipakai sehari-hari. Reuse (memakai kembali): memperpanjang waktu pemakaian barang sebelum ia menjadi sampah/menghindari pemakaian sekali pakai. Recycle (mendaur ulang): sedapat mungkin mendaur ulang barang-barang yang sudah tidak terpakai lagi menjadi bentuk dan fungsi lain, meski tidak semua 
barang bisa di daur ulang. Menurut Slamet (1994), ada beberapa faktor yang penting yang mempengaruhi sampah yaitu: jumlah penduduk, keadaan sosial, kemajuan Teknologi yang akan menambah jumlah maupun kualitas sampah.

$$
\text { Pengelolaan sampah yang }
$$

berwawasan lingkungan akan:

1. Mengurangi volume sampah yang masuk ke TPA sehingga dapat memperpanjang umur tempat pembuangan akhir (TPA), meningkatkan efisiensi biaya pengangkutan sampah, meningkatnya kondisi sanitasi di sekitar TPA.

2. Mengurangi pencemaran lingkungan dan meningkatkan kebersihan lingkungan.

3. Membantu melestarikan sumberdaya alam, terutama kompos yang dipakai untuk pupuk tanaman.

4. Menghasilkan sumberdaya baru dari sampah, misalnya pupuk tanaman.

5. Meningkatkan peran serta masyarakat dalam pengelolaan sampah dan meningkatkan pendapatan masyarakat.

Bertambahnya jumlah sampah dalam suatu wilayah, menurut Chairuddin (2003), berkorelasi dengan jumlah populasi manusia dan banyaknya aktivitas yang dilakukan di dalam suatu komunitas. Jumlah penduduk Kota Pontianak berdasarkan data Dinas Kependudukan dan Pencatatan Sipil Tahun 2013 berjumlah 1.116.175 dengan rincian sebagai berikut: penduduk laki-laki sebanyak 581.218 jiwa dan penduduk perempuan 534.957 jiwa. Sedangkan jumlah WNA laki-laki 3.294 jiwa dan perempuan sebanyak 1.180 jiwa. Meningkatnya jumlah penduduk pendatang dan aktivitas yang dilakukan untuk meningkatkan pertumbuhan ekonomi akan berpengaruh terhadap meningkatnya volume sampah di Kota Pontianak.
Kota Pontianak sebagaimana kota lain di Indonesia juga mempunyai permasalahan yang umum terjadi dalam pengelolaan persampahan kota. Masalah yang sering muncul dalam penanganan sampah kota adalah masalah biaya operasional yang tinggi. Sebagai akibat biaya operasional yang tinggi, kebanyakan kota-kota di Indonesia hanya mampu mengumpulkan dan membuang \pm $60 \%$ dari seluruh produksi sampahnya.

Setiap harinya menghasilkan 300 ton sampah dan 30 persen di antaranya merupakan sampah anorganik yang bisa dimanfaatkan kembali. Saat ini, hampir 100 persen sampah di Kota Pontianak dibuang ke Tempat Pembuangan Akhir (TPA) Batu Layang yang merupakan satusatunya TPA di Kota Pontianak. Dengan model pengelolaan sampah seperti sekarang, TPA Batu Layang akan penuh dalam waktu delapan tahun kedepan. Kondisi tersebut tentu menyebabkan TPA tidak dapat digunakan secara maksimal untuk menampung sampah yang dihasilkan.

Dalam mengatasi permasalahan sampah di Kota Pontianak, perlu ada strategi pengelolaan yang berkesinambungan dan tidak mencemari lingkungan sehingga pengelolaan sampah terkelola dengan tepat dan berwasawan lingkungan. Saat ini Kota Pontianak bekerjasama dengan masyarakat menciptakan inovasi dalam pengelolaan sampah berbasis aplikasi dengan memanfaatkan teknologi informasi yang mutakhir dalam mengelola sampah. Dengan adanya inovasi tersebut diharapkan mampu mengatasi permasalahan sampah di Kota Pontianak.

ANGKUT'S atau singkatan dari Angkut Sampah hadir sebagai solusi atas permasalah tersebut. Hafiz, pemuda Pontianak sang penggagas program mengungkapkan, ANGKUT'S merupakan sebuah start up sociopreneur berbasis teknologi yang menyediakan solusi 
masalah sampah di Kota Pontianak dengan metode "dipilah, di ANGKUT'S, dimanfaatkan". "ANGKUT'S juga mengedukasi penduduk kota untuk menjadi bagian dari solusi masalah sampah dengan menjadi warga kota yang smart dalam mengelola sampah. Beranjak dari permasalahan di atas, penulis tertarik untuk melakukan kajian tentang permasalahan sampah dan menuangkannya dalam penelitian yang berjudul "Inovasi Manajemen Pengelolaan Sampah Yang Berwawasan Lingkungan di Kota Pontianak Berbasis Aplikasi”.

\section{KAJIAN LITERATUR}

Istilah inovasi memang selalu diartikan secara berbeda-beda oleh beberapa ahli. Menurut Suryani (208:304), Inovasi dalam konsep yang luas sebenarnya tidak hanya terbatas pada produk. Inovasi dapat berupa ide, caracara ataupun obyek yang dipersepsikan oleh seseorang sebagai sesuatu yang baru. Inovasi juga sering digunakan untuk merujuk pada perubahan yang dirasakan sebagai hal yang baru oleh masyarakat yang mengalami. Namun demikian, dalam konteks pemasaran dan konteks perilaku konsumen inovasi dikaitkan dengan produk atau jasa yang sifatnya baru. Baru untuk merujuk pada produk yang memang benar-benar belum pernah ada sebelumnya di pasar dan baru dalam arti ada hal yang berbeda yang merupakan penyempurnan atau perbaikan dari produk sebelumnya yang pernah ditemui konsumen di pasar.

Kata inovasi dapat diartikan sebagai "proses" atau "hasil" pengembangan dan atau pemanfatan atau mobilsasi pengetahuan, keterampilan (termasuk keterampilan teknologis) dan pengalaman untuk menciptakan atau memperbaiki produk, proses yang dapat memberikan nilai yang lebih berarti. Menurut
Rosenfeld dalam Sutarno (2012:132), inovasi adalah transformasi pengetahuan kepada produk, proses dan jasa baru, tindakan mengunakan sesuatu yang baru. Sedangkan menurut Mitra pada buku tersebut dan pada halaman yang sama, bahwa inovasi merupakan eksploitasi yang berhasil dari suatu gagasan baru atau dengan kata lain merupakan mobilsasi pengetahuan, keterampilan teknologis dan pengalaman untuk menciptakan produk, proses dan jasa baru. Namun menurut Vontana 209:20), inovasi adalah kesuksesan ekonomi dan sosial berkat diperkenalkanya cara baru atau kombinasi baru dari cara-cara lama dalam mentransformasi input menjadi output yang menciptakan perubahan besar dalam hubungan antara nilai guna dan harga yang ditawarkan kepada konsumen dan/atau penguna, komunitas, sosietas dan lingkungan.

Hampir sama dengan inovasi organisasi menurut Sutarno (2012:134135) yang didefinisikan sebagai cara-cara baru dalam pengaturan kerja, dan dilakukan dalam sebuah organisasi untuk mendorong dan mempromosikan keungulan kompetif. Inti dari inovasi organisasi adalah kebutuhan untuk memperbaiki atau mengubah suatu produk, proses atau jasa. Inovasi organisasi mendorong individu untuk berpikir secara mandiri dan kreatif dalam menerapkan pengetahuan pribadi untuk tantangan organisasi. Semua organisasi bisa berinovasi termasuk untuk organisasi perusahan, rumah sakit, universitas, dan organisasi pemerintahan. Pentingnya nilai, pengetahuan dan pembelajaran dalam inovasi organisasi sangat penting.

Inovasi erat kaitanya teknologi dan informasi, khususnya internet, memilki peranan penting dalam meningkatkan transparansi. Richard Heks dalam LAN (207:98) mengelompokan manfat ekonologi nformasi dan komunikasi dalam dua kelompok, yaitu: 
1. Manfaat pada Tingkat Proses

a. Menghemat biaya: mengurangi biaya transaksi bagi masyarakat untuk akses ke informasi pemerintah dan mengirim informasi ke pemerintah, mengurangi biaya bagi pemerintah untuk menyediakan inoformasi.

b. Menghemat waktu: mempercepat proses internal dan proses pertukaran data dengan instansi lain.

c. Mengurangi keterbatasan: dimanapun, kapanpun informasi dan layanan pemerintah dapat diakses oleh masyarakat.

d. Keputusan yang lebih baik: pimpinan dapat mengontrol kinerja stafnya, mengontrol kegiatan, ataupun mengontrol kebutuhan.

2. Manfat pada Tingkat Pengelolan

a. Merubah perilaku aparatur: mengurangi interes pribadi dan meningkatkan interes rasional atau nasional. Misalnya dalam mengurangi tindakan korupsi, mengurangi pemalsuan, kerja lebih efektif dan efisien dan perlakuan terhadap masyarakat yang lebih setara dalam pelayanan publik.

b. Merubah perilaku masyarakat: partisipasi yang lebih besar terhadap proses pemerintahan dan memperluas kesempatan pemasok untuk ambil bagian dalam pelayanan pengadan barang atau jasa.

c. Pemberdayan: meningkatkan keseimbangan kekuatan antar kelompok, melalui kemudahan, akses ke informasi kepemerintahan. Pemberdayan aparatur lebih meningkat melalui akses ke informasi yang dibutuhkan mereka dalam menjalankan tugas dan fungsinya, pemberdayan pemasok melalui akses ke informasi tentang pengadan barang dan jasa dan pemberdayan manajer melalui akses ke informasi mengenai stafnya dan sumberdaya lainya

Sampah pada dasarnya merupakan suatu bahan yang terbuang atau di buang dari suatu sumber hasil aktivitas manusia maupun proses-proses alam yang tidak mempunyai nilai ekonomi, bahkan dapat mempunyai nilai ekonomi yang negatif karena dalam penanganannya baik untuk membuang atau membersihkannya memerlukan biaya yang cukup besar. Sampah adalah bahan yang tidak mempunyai nilai atau tidak berharga untuk maksud biasa atau utama dalam pembikinan atau pemakaian barang rusak atau bercacat dalam pembikinan manufktur atau materi berkelebihan atau ditolak atau buangan (Kementerian Lingkungan Hidup, 2005). Dalam Undang-Undang No.18 tentang Pengelolaan Sampah dinyatakan definisi sampah sebagai sisa kegiatan sehari-hari manusia dan/atau dari proses alam yang berbentuk padat.

Sampah adalah sesuatu yang tidak berguna lagi, dibuang oleh pemiliknya atau pemakai semula (Tandjung, 1982 dalam Suprihatin, 1999). Pemerintah bertanggung jawab dalam pengumpulan ulang dan penbuangan sampah dari pemukiman secara memadai. Namun karena terdapat hal lain yang harus diprioritaskan dalam pembangunan di daerah serta kurangnya dana penunjang untuk operasionalisasi pengelolaan persampahan, menjadikan pada beberapa daerah kegiatan pengelolaan sampah ini tidak seperti yang diharapkan.

Hal ini makin diperkuat dengan belum diterapkannya prinsip bahwa yang memproduksi barang harus mengelola sampah dari barang tesebut. Beberapa kondisi umum yang terjadi dalam pelaksanaan pengelolaan sampah perkotaan selama ini, di mana sampah rumah tangga oleh masyarakat dikumpulkan dan dibuang ke sebuah 
tempat pembuangan atau kontainer yang disediakan oleh pemerintah. Dari sini sampah diangkut oleh truk ke landfill yang umumnya kurang terkontrol, dimana para pemulung mencari barang-barang yang dapat didaur ulang.

Keberadaan sampah dalam jumlah yang banyak jika tidak dikelola secara baik dan benar, maka akan menimbulkan gangguan dan dampak terhadap lingkungan, baik dampak terhadap komponen fisik kimia (kualitas air dan udara), biologi, sosial ekonomi, budaya dan kesehatan lingkungan. Dampak operasional TPA terhadap lingkungan akan memicu terjadinya konflik sosial antar komponen masyarakat.Pada tahap pembuangan akhir/pengolahan, sampah akan mengalami pemrosesan baik secara fisik, kimia maupun biologis sedemikian hingga tuntas penyelesaian seluruh proses.

Dalam Undang-Undang No. 18 tahun 2008 tentang Pengelolaan Sampah, jenis sampah yang diatur adalah:

1. Sampah rumah tangga

Sampah rumah tangga yaitu sampah yang berbentuk padat yang berasal dari sisa kegiatan sehari-hari di rumah tangga, tidak termasuk tinja dan sampah spesifik dan dari proses alam yang berasal dari lingkungan rumah tangga. Sampah ini bersumber dari rumah atau dari komplek perumahan.

2. Sampah sejenis sampah rumah tangga

Sampah sejenis sampah rumah tangga yaitu sampah rumah tangga yang bersala bukan dari rumah tangga dan lingkungan rumah tangga melainkan berasal dari sumber lain seperti pasar, pusat perdagangan, kantor, sekolah, rumah sakit, rumah makan, hotel, terminal, pelabuhan, industri, taman kota, dan lainnya.

3. Sampah spesifik

Sampah spesifik yaitu sampah rumah tangga atau sampah sejenis rumah tangga yang karena sifat,konsentrasi dan/atau jumlahnya memerlukan penanganan khusus, meliputi, sampah yang mengandung B3 (bahan berbahaya dan beracun seperti batere bekas, bekas toner, dan sebagainya), sampah yang mengandung limbah B3 (sampah medis), sampah akibat bencana, puing bongkaran, sampah yang secara teknologi belum dapat diolah, sampah yang timbul secara periode (sampah hasil kerja bakti).

Mekanisme pengelolaan sampah dalam UU N0.18 Tahun 2008 tentang Pengelolaan Sampah meliputi, kegiatankegiatan berikut:

1. Pengurangan sampah, yaitu kegiatan untuk mengatasi timbulnya sampah sejak dari produsen sampah (rumah tangga, pasar, dan lainnya), mengguna ulang sampah dari sumbernya dan/atau di tempat pengolahan, dan daur ulang sampah di sumbernya dan atau di tempat pengolahan. Pengurangan sampah akan diatur dalam Peraturan Menteri tersendiri, kegiatan yang termasuk dalam pengurangan sampah ini adalah:

a. Menetapkan sasaran pengurangan sampah

b. Mengembangkan Teknologi bersih dan label produk

c. Menggunakan bahan produksi yang dapat di daur ulang atau diguna ulang

d. Fasilitas kegiatan guna atau daur ulang

e. Mengembangkan kesadaran program guna ulang atau daur ulang

2. Penanganan sampah, yaitu rangkaian kegiatan penaganan sampah yang mencakup pemilahan (pengelompokan dan pemisahan sampah menurut jenis dan sifatnya), pengumpulan (memindahkan sampah dari sumber sampah ke TPS atau tempat pengolahan sampah terpadu), pengangkutan (kegiatan memindahkan sampah dari sumber, TPS atua tempat pengolahan sampah terpadu, 
pengolahan hasil akhir (mengubah bentuk, komposisi, karateristik dan jumlah sampah agar diproses lebih lanjut, dimanfaatkan atau dikembalikan alam dan pemprosesan aktif kegiatan pengolahan sampah atau residu hasil pengolahan sebelumnya agar dapat dikembalikan ke media lingkungan.

Pemerintah Daerah diharapkan dapat melakukan kebijakan politik khususnya mengenai pengelolaan sampah dan hendaknya didukung penuh oleh Pemerintah Pusat dengan melibatkan seluruh stakeholder dalam teknis perencanaan, penyelenggaraan dan pengembangannya. Hal ini diperlukan karena sampah pada dasarnya bukan sekedar permasalahan Pemda atau Dinas Kebersihan Kota Pontianak saja, namun lebih dari itu merupakan masalah bagi setiap individu, keluarga, organisasi dan akan menjadi masalah negara bila sistem perencanaan dan pelaksanaannya tidak dilakukan dengan terpadu dan berkelanjutan.

Aparat terkait sebaiknya tidak ikut secara teknis, ini untuk menghindari meningkatnya anggaran biaya penyelenggaraan, selain itu keterlibatan aparat terkait dikahawatirkan akan membentuk budaya masyarakat yang bersifat tidak peduli. Pemerintah dan aparat terkait sebaiknya memposisikan kewenangannya sebagai fisilitator dan konduktor dan setiap permasalahan persampahan sebaiknya dimunculkan oleh masyarakat atau organisasi sosial selaku produsen sampah. Hal ini diharapkan terciptanya sikap masyarakat selaku individu, keluarga dan organisasi.

Dalam Pengelolaan Sampah Terpadu sebagai salah satu upaya pengelolaan Sampah Perkotaan adalah konsep rencana pengelolaan sampah perlu dibuat dengan tujuan mengembangkan suatu sistem pengelolaaan sampah yang modern, dapat diandalkan dan efisien dengan teknologi yang ramah lingkungan. Dalam sistem tersebut harus dapat melayani seluruh penduduk, meningkatkan standar kesehatan masyarakat dan memberikan peluang bagi masyarakat dan pihak swasta untuk berpartisipasi aktif.

Aboejoewono (1999) menyatakan bahwa perlunya kebijakan pengelolaan sampah perkotaan yang berwawasan lingkungan mengacu ditetapkan di kotakota di Indonesia meliputi 5 (lima) kegiatan, yaitu:

1. Penerapan teknologi yang tepat guna

2. Peran serta masyarakat dalam pengelolaan sampah

3. Perlunya mekanisme keuntungan dalam pengelolaan sampah

4. Optimalisasi TPA sampah

5. Sistem kelembagaan pengelolaan sampah yang terintegrasi

Menurut Terry (1991) manajemen adalah suatu proses atau kerangka kerja yang melibatkan bimbingan atau pengarahan suatu kelompok orang ke arah tujuan-tujuan organisasional atau maksudmaksud yang nyata. Manajemen merupakan suatu bentuk kegiatan, atau disebut "managing", sedangkan pelaksananya disebut dengan "manager" atau pengelola. Manajemen juga adalah suatu ilmu pengetahuan maupun seni. Seni adalah suatu pengetahuan bagaimana mencapai hasil yang diinginkan atau dalam kata lain seni adalah kecakapan yang diperoleh dari pengalaman, pengamatan, dan pelajaran serta kemampuan untuk menggunakan pengetahuan manajemen.

Kota berwawasan lingkungan adalah satu pendekatan pembangunan kota yang didasarkan atas prinsip-prinsip berwawasan lingkungan/ekologis yang akan menghasilkan satu kota yang mempunyai kualitas lingkungan dan kehidupan yang lebih baik dan berkelanjutan. Kota berwawasan 
lingkungan/ekologis berarti juga kota yang berkelanjutan, dalam pengertian bahwa masa depan kota diharapkan akan menjadi lebih baik dan lestari. Kota ekologis dengan sendirinya juga merupakan kota yang ramah lingkungan, karena prinsip-prinsip kota ekologis sejalan dengan prinsip konservasi lingkungan. Kota Ekologis diperlukan untuk menjawab tantangan persoalan lingkungan kota yang semakin memburuk dan hal ini disebabkan karena pendekatan pembangunan kota yang berlaku berorientasi pada aspek ekonomi jangka pendek semata. Kota ekologis sangat krusial bagi Indonesia, karena tingkat urbanisasi dan perkembangan kota yang sangat pesat di Indonesia. Kota berwawasan lingkungan merupakan salah satu jawaban membangun kota yang lebih baik karena secara efisien menggunakan sumber daya kota. Hal ini dapat dilakukan dengan menekan penggunaan sumberdaya, meminimalkan jumlah limbah, mengurangi panggunaan air, udara, tumbuhan, fauna, pantai ataupun danau dengan komponen buatan jalan, bangunan, jembatan, dan jaringan sarana prasarana kota.

\section{METODE PENELITIAN}

Penelitian ini menggunakan metode pendekatan kualitatif bersifat deskriptif. Pendekatan ini dipilih karena tujuan utama dari penelitian adalah untuk mencari, memahami, mendeskripsikan dan menganalisa secara lebih mendalam fenomena yang dijadikan penelitian.

Adapun fokus dalam peneiltian ini adalah ingin mengetahui bagaimana manajemen pengelolaan sampah yang meliputi aspek teknis operasional dan aspek non teknis di Kota Pontianak Dalam penelitian kualitatif, ada yang disebut dengan batasan masalah. Batasan masalah dalam penelitian kualitatif disebut dengan fokus yang berisi pokok masalah (Sugiyono, 2008 : 206). Apabila tidak dibatasi dimungkinkan akan terjebak pada melimpahnya volume data yang diperoleh dilapangan. Lokasi penelitian adalah di Lingkungan Pemerintah Kota Pontianak Provinsi Kalimantan Barat Khususnya di Dinas Kebersihan dan Pertamanan serta pihak-pihak yang terlibat dalam lokus

Sumber-sumber data dalam penelitian ini adalah:

a. Informan, kata-kata dan tindakan dari informan yang diamati atau diwawancara merupakan sumber utama dalam penelitian ini.

b. Dokumen/sumber tertulis, digunakan dalam penelitian sebagai sumber data karena dalam banyak hal dokumen sebagai sumber data dapat dimanfaatkan untuk menguji, menafsirkan, bahkan untuk meramalkan. Dokumen sumber tertulis berasal dari buku, majalah ilmiah, sumber dari arsip, dokumen pribadi dan dokumen resmi.

c. Tempat dan peristiwa sebagai sumber data tambahan dilakukan melalui observasi langsung terhadap tempat dan peristiwa yang berkaitan dengan peran strategis kecamatan dalam pelayanan publik.

Adapun teknik pengumpulan data yang dipergunakan dalam penelitian ini diantaranya Teknik wawancara (interview), yaitu melakukan tanya jawab antara peneliti dengan nara sumber yang dianggap layak atau relevan dalam penelitian ini, observasi, yaitu peneliti bertindak sebagai pengamat dan hanya membuat kategori perilaku, mengamati gejala dan mencatatnya dalam buku observasinya, dokumentasi, yaitu pengumpulan bahan-bahan atau data yang berasal dari dokumentasi langsung objek penelitian juga surat kabar serta Studi pustaka, yaitu dilaksanakan terutama untuk menyusun kerangka teori serta mencari konsep-konsep yang berkaitan dengan masalah penelitian dari buku-buku 
dan sumber-sumber bacaan lainya yang berhubungan dengan judul tesis ini.

Analisis data menurut Patton dalam bukunya Moleong (2000:103), adalah proses mengatur urutan data, mengorganisasikan ke dalam suatu pola, kategori dan satuan uraian besar. Sesuai dengan metode penelitian, teknik analisis data yang digunakan oleh peneliti adalah metode deskriptif dengan pendekatan kualitatif yaitu, proses penggambaran daerah penelitian. Pengolahan data dalam penelitian ini dilakukan dengan 4 (empat) tahap diantaranya pertama Pengumpulan Data (Field Note); peneliti mencatat semua data secara objektif dan apa adanya sesuai dengan hasil observasi dan interview di lapangan, kedua Reduksi data; diartikan sebagai proses pemilihan, pemusatan perhatian pada penyederhanaan, pengabstrakan dan transformasi data-data "kasar" yang muncul dari catatan-catatan tertulis di lapangan, Ketiga Sajian data; adalah sekumpulan informasi tersusun yang memberi kemungkinan adanya penarikan kesimpulan dan pengambilan tindakan, dan yang Keempat Kesimpulan/verifikasi data; didasarkan pada reduksi data dan sajian data yang merupakan jawaban atas masalah yang diangkat dalam penelitian.

\section{HASIL}

\section{a. Manajemen Pengelolaan Sampah di Kota Pontianak}

Sampah merupakan suatu materi yang tidak digunakan, tidak terpakai, tidak disenangi, atau suatu yang dibuang yang berasal dari kegiatan manusia. Pengelolaan sampah yang kurang baik dapat memberikan pengaruh negatif terhadap kesehatan (Mukono, 2000:25). Setiap hari kita tidak dapat lepas dari sampah, karena kita membuangnya baik di rumah atau di kantor, industri dan dimanapun kita berada sehingga akan menimbulkan pencemaran tanah, air, dan udara. Sampah menjadi masalah yang hampir dihadapi setiap kota-kota yang ada di dunia tidak terkecuali kota-kota di Indonesia termasuk Kota Pontianak sendiri.

Begitu kompleksnya permasalahan sampah, maka dibutuhkan manajemen terpadu dalam pengelolaan sampah. Manajemen dalam pengelolaan sampah dapat ditinjau dari dua aspek diantaranya aspek teknis operasional dan aspek non teknis. Aspek teknis operasional dilihat dari pewadahan, pengumpulan, pemindahan, pengangkutan, pengolahan pendaurulangan dan pembuangan akhir sampah. Sementara dari aspek non teknis dapat dilihat dari organisasi/kelembagaan, peraturan/produk hukum, penbiayaan dan partisipasi masyarakat.

Manajemen pengelolaan sampah di Kota Pontianak pada prinsipnya telah berusaha untuk melaksanakan pengelolaan sampah sesuai dengan aspek teknis dan non teknis seperti yang diamanatkan oleh Undang-undang Nomor 18 Tahun 2008 dimana setiap daerah wajib melaksanakan pengelolaan sampah sesuai dengan standar dan aturan yang telah di tuangkan dalam produk hukum perundang-undangan tersebut. Untuk pengelolaan sampah spesifik semacam sampah yang tergolong B3 (bahan berbahaya dan beracun) dan sampah medis yang bersifat infektius mengenai pengelolaanya telah diatur dalam Peraturan Pemerintahan Nomor 18 Tahun 1999 tentang Pengelolaan Limbah Bahan Berbahaya dan Beracun dan Peraturan Pemerintah Nomor 85 Tahun 1999 tentang Perubahan Atas Peraturan Pemerintah Nomor 18 Tahun 1999 tentang Pengelolaan Limbah Bahan Berbahaya dan Beracun.

b. Aspek Teknis $\begin{array}{r}\text { Operasional } \\ \text { Pengelolaan } \\ \text { Pontianak }\end{array}$


Pada tahap penampungan/pewadahan sampah yang dilakukan oleh masyarakat yang ada di Kota Pontianak. Diketahui bahwa masyarakat biasanya mengunakan wadah berupa tong, keranjang bambu, dan bin (drum plastik), dan bak sampah permanen. Wadah tersebut diletakkan di depan rumah dan kemudian diangkut oleh pengelola sampah. Penduduk di Kota Pontianak umumnya tidak melakukan pemilahan sampah antara organik dan anorganik. Sehingga dapat dikatakan bahwa pola pewadahan di Kota Pontianak masih menggunakan sistem pewadahan individual. Hasil pengumpulan nantinya akan diangkut petugas kebersihan dan pertamanan yang mengambil sampah tersebut kemudian langsung dibuang ke tempat pembuangan akhir (TPA) Batu Layang.

Dalam rangka mengetahui komposisi sampah rumah tangga di wilayah penelitian, dilakukan observasi pada timbulan sampah rumah tangga di beberapa tempat di Kota Pontianak dan di TPA Batu Layang. Dengan keterbatasan kesempatan yang ada, penelitian tidak memungkinkan melakukan observasi terhadap seluruh sampah yang dihasilkan. Sehingga penelitian hanya melakukan observasi dan diketahui bahwa sampah dari rumah tangga di wilayah penelitian terdiri dari jenis sampah organik plastik kertas dan sampah campur, belum termasuk sampah yang bersifat B3 yang merupakan sampah dari hasil kegiatan industri-industri yang ada di Kota Pontianak.

Dari temuan di lapangan tersebut menunjukkan bahwa sampah rumah tangga sebenarnya mengandung potensi yang sangat besar untuk dimanfaatkan kembali dan memiliki nilai ekonomis. Sampah organik yang ada di Kota Pontianak sampai saat ini belum dimanfaatkan oleh masyarakat sebagai bahan kompos (pupuk), yaitu berupa pupuk padat dan pupuk cair. Sedangkan sampah plastik, kertas, kaca dan logam sebenarnya apabila dikelola dan dipilah akan mempunyai nilai ekonomi yang tinggi. Hal ini belum dilakukan di Kota Pontianak, kalaupun ada dalam skala kecil. Dan biasanya pemulung yang memunguti plastik, atau kertas dan selanjutnya dijual. Sehingga dapat dikatakan bahwa kesadaran masyarakat terkait pemilahan sampah masih sangat kurang.

Tahan pengangkutan sampah di Kota Pontianak dari sumber yaitu rumah tangga ke TPA Batu Layang dengan menggunakan mobil bak terbuka. Intensitas pengambilan sampah ataupun pengangkutan dilakukan secara berbeda oleh petugas kebersihan. Sistem pengangkuan individual langsung (door to door). Namun dalam pengangkutanbsampah ke TPA seringkali terjadi keterlambatan pengangkutan oleh mobil petugas kebersihan, sehingga muncul dmapak sampah yang berserakan saat pengangkutan smapah, mdan menimbulkan pencemaran udara karena bau dari sampah tersebut saat pengangkutan dan melalui pemukiman warga.

\section{c. Aspek Hukum dan Peraturan}

Berdasarkan hasil penelitian tentang aspek hukum dan peraturan mengenai persampahan, bahwa di Kota Pontianak hukum dan epraturanada yaitu peraturan daerah Kota Pontianak Nomor 5 Tahun 2001 tentang kebersihan Kota Pontianak, kemudian untuk menjalankan teknisnya dikeluarkan Peraturan Wali Kota Pontianak Nomor 35 Tahun 2011 tentang petunjuk pelaksanaan peraturan daerah tersebut. Peraturan daerah terbaru yakni Peraturan Daerah Nomor 11 Tahun 2013 tentang Pengelolaan Sampah. Dalam Peraturan Daerah tersebut telah diatur pengelolaan sampah Kota Pontianak yang di mulai dari pengelolaan, pemilahan, pengumpulan, dan pengolahan sampah. 
Kerjasama pengelolaan sampah juga telah di atur dalam peraturan daerah tersebut, seperti yang terdapat dalam Bab III pasal 13 "Kegiatan pengelolaan kebersihan dapat dikerjasamakan dengan badan usaha yang berbadan hukum dan memiliki kemampuan atau kualifikasi untuk menyelenggarakan pengelolaan kebersihan dengan mengacu kepadaketentuan yang berlaku tentang kerjasama pemerintah daerah dan swasta.

Dengan adanya Peraturan Daerah tersebut sejatinya harus di implementasikan sehingga produk hukum yang telah diformulasikan bisa memberikan dampak terhadap pengelolaan sampah yang berwawasan lingkungan sesuai dengan amanat UU Nomor 18 tahun 2008. Namun peraturan daerah tersebut belum sepenuhnya bisa dijalankan di Kota Pontianak. Produk hukum dan peraturan tentang penelgolaan smapah sudah ada, namun belum bisa sepenuhnya diimplementasikan. Meskipun sudah disahkan namun Perda tersebut belum bisa diimplementasikan karena belum bisa disosialisasikan secara optimal. Lahirnya perda tersebut merupakan payung hukum dalam penerapan paradigma baru pengelolaan smapah sesuai amana Undang-Undang Nomro 18 Tahun 2008.

\section{d. Aspek Pembiayaan}

Berdasarkan hasil penelitian tentang aspek pembiayaan dan retribusi, diketahui bahwa masyarakat Kota Pontianak mempunyai kewajiban membayar retribusi dan iuran kebersihan. Besarnya retribusi ditentukan berdasarkan jumlah smpah yang dihasilkan oleh masyarakat. Rata-rata warga membayar Rp 7.000 15.000 per rumah per bulan, sedangkan untuk toko makanan sekitar Rp 35.000,00. untuk pembayarannya langsung ditagih pada awal bulan oleh pengelola sampah. Akan tetapi, biaya operasional dan pemeliharaan mobil sepenuhnya menjadi kewajiban pengelola smapah yakni Dinas Kebersihan dan Pertamanan Kota Pontianak. Aspek pembiayaan dan retribusi telah diatur dalam peraturan Daerah Kota Pontianak No 3 Tahun 2012 tentang perubahan atas peraturan daerah Nomor 4 Tahun 2011Tentang Retribusi jasa Umum yang pelaksanaanya diatur dalam peraturan Wali Kota Pontianak Nomor 30 Tahun 2017 tentang petunjuk pelaksanaan pemungutan retribusi pelayanan persamapahan/kebersihan.

Guna memenuhi Pendapatan Asli daerah (PAD) Kota Pontianak, Pemerintah Kota Pontianak melalui Dinas Lingkungan Hidup (DLH) menetapkan tarif retribusi sampah terhadap Pedagang pasar tradisional, Usaha atau jasa dan pemukiman penduduk. Retribusi pelayanan persampahan/kebersihan kota Pontianak ini sesuai dengan Perda Nomor 16 tahun 2015 tentang perubahan kedua atas peraturan daerah nomor 4 tahun 2011 tentang retribusi jasa umum, pasal (1) ayat 52 retribusi pelayanan persampahan/kebersihan.

Retribusi untuk pemukiman/perumahan di bagi dalam tiga golongan berdasarkan lebar jalan dan luas rumah. Golongan ekonomi I yaitu rumah yang berlokasi dijalan selebar minimal 6,5 meter, untuk rumah bertingkat dikenakan tarif retribusi Rp 15.000 dan untuk rumah tingkat bertingkat Rp 11.500. Golongan ekonomi II, yaitu rumah dengan lebar jalan 4-6,5 meter, untuk rumah bertingkat dikenakan tarif $\mathrm{Rp} 11.500$ dan untuk rumah tidak bertingkat $\mathrm{Rp} \quad 7.500$. Golongan ekonomi III, yaitu rumah dengan lebar jalan kurang dari 4meter, untuk rumah bertingkat $\mathrm{Rp} 5.500$ dan untuk rumah tidak bertingkat Rp 2.500 . kemudian retribusi untuk Usaha dan Jasa, luas usaha kurang dari 40 meter persegi (toko/kios) dikenakan tarif retribusi sampah sebesar Rp 30.000, luas usaha lebih dari 40 meter persegi dikenakan tarif Rp 100.000, kemudian usaha los, tenda, 
meja, gerobak dikenakan tarif retribusi sampah sebesar $\mathrm{Rp} 1.500$ perhari atau $\mathrm{Rp}$ 40.000 perbulan.

Aspek pembiayaan dalam pengelolaan sampah menjadi aspek yang krusial dan sensitif karena berkaitan dnegan keuangan. Pembiayaan dalam pengelolaan sampah Kota Pontianak cukup besar mengingat sampah yang ada di Kota Pontianak tersebut dalam sehari jumlah sampah yang masuk ke TPA kurang lebih 350-400 ton/hari (data DLH tahun 2012). banyaknya penduduk dan rumah tangga yang ada di Kota Pontianak mempengaruhi volume sampah dan kebersihan

Berdasarkan penelitian dan observasi tentang aspek peran serta masyarakat, bahwa selama ini peran masyarakat dalam pengelolaan sampah terlihat dari keterlibatan masyarakat dalam kegiatan pewadahan sampah, sedangkan untuk pemilahan sampah masyarakat tidak memilah sampah mana yang sampah organic dan mana sampah anorganik. Biasanya sampah langsung ditumpuk dalam tong atau kantong plastik selanjutnya ditumpuk di tempat sampah. Partisipasi pembayaran retribusi sampah sudah berjalan dengan baik. Sedangkan pengumpulan sampah untuk didaur ulang dan pemanfaatan sampah untuk pengomposan belum ada masyarakat yang melakukan kegiatan tersebut.

\section{e. Manajemen Pengelolaan Sampah yang Berwawasan Lingkungan}

Fenomena pertambahan jumlah penduduk, perubahan pola konsumsi, dan gaya hidup masyarakat telah meningkatkan jumlah timbulan sampah, jenis, dan keberagaman karakteristik sampah. Meningkatnya daya beli masyarakat terhadap berbagai jenis bahan pokok dan hasil teknologi serta meningkatnya usaha atau kegiatan penunjang pertumbuhan ekonomi suatu daerah juga memberikan kontirbusi yang besar terhadap kuantitas dan kualitas sampah yang dihasilkan. Meningkatnya volume timbulan sampah memerlukan pengelolaan. Pengelolaan sampah yang tidak mempergunakan metode dan teknik pengelolaan sampah yang ramah lingkungan selain akan dapat menimbulkan dampak negative terhadap kesehatan juga akan sangat mengganggu kelestarian fungsi lingkungan baik lingkungan pemukiman, hutan, persawahan, sungai dan lautan.

Berdasarkan Undang-Undang No. 18 Tahun 2008, sampah adalah sisa kegiatan sehari-hari manusia dan/atau proses alam yang berbentuk padat. Pengelolaan sampah dimaksudkan adalah kegiatan yang sistematis, menyeluruh, dan berkesinambungan yang meliputi pengurangan dan penanganan sampah, sehingga pengelolaan sampah memang betul-betul berwawasan lingkungan, memperhatikan kelestarian lingkungan yang pada akhirnya keberlangsungan hidup akan berlanjut secara sehat.

Pengelolaan sampah di Kota Pontianak menemui banyak permasalahan mulai dari aspek operasional teknis seperti perwadahan, pengumpulan, pemindahan, pengangkutan,

pengolahan/pendaurulangan sampai pada pembuangan akhir sampah. Disamping aspek opersional teknis permasalahan aspek non teknis juga dapat terjadi.

\section{f. Aspek Operasional Teknis}

Pengelolaan sampah Kota Pontianak kalau dilihat dari aspek operasional teknis yang meliputi perwadahan, pengumpulan, pemindahan, pengangkutan, pengolahan/pendaurulangan sampai pada pembuangan akhir sampah bisa dikatakan belum memenuhi standar yang telah ditetapkan dalam Undang-Undang Nomor 18 Tahun 2008. Dimana dalam undangundang tersebut pengelolaan sampah haru memenuhi standar seperti rangkaian kegiatan penaganan sampah yang 
mencakup pemilahan (pengelompokan dan pemisahan sampah menurut jenis dan sifatnya), pengumpulan (memindahkan sampah dari sumber sampah ke TPS atau tempat pengelolaan terpadu), pengangkutan (kegiatan memindahkan sampah dari sumber, TPS atau tempat pengelolaan sampah terpadu, pengelolaan hasil akhir (mengubah bentuk, komposisi, karakteristik dan jumlah sampah agar dip roses lebih lanjut, dimanfaatkan atau dikembalikan alam dan pemprosesan aktif kegiatan pengelolaan sampah atau residu hasil pengelolaan sebelumnya agar dapat dikembalikan ke media lingkungan.

Aboejoewono (1999) menyatakan bahwa perlunya kebijakan pengelolaan sampah perkotaan yang berwawasan lingkungan mengaku ditetapkan di kotakota di Indonesia meliputi 5 (lima) kegiatan, yaitu : 1) Penetapan teknologi yang tepat guna, 2) Peran serta masyarakat dalam mengelolaan sampah, 3) Perlunya mekanisme keuntungan dalam pengelolaan sampah, 4) Optimalisasi TPA sampah yang tidak merusak lingkungan baik air dan udara, 5) Sistem kelembagaan pengelolaan sampah yang terintegrasi.

$\begin{array}{ccr}\text { Namun berdasarkan } & \text { data dan } \\ \text { observasi } & \text { dilapangan } & \text { terhadap } \\ \text { permasalahan-permasalahan } & \text { dalam }\end{array}$
pengelolaan sampah di Kota Pontianak diantarannya: 1) Belum adanya penerapan teknologi tepat guna baik skala kecil maupun besar. Hal ini masih ditandai dengan modal pengelolaan sampah yang masih memakai paradigm lama dalam pengelolaan sampah. Kalaupun ada itu baru sebatas wacana, 2) Peran serta masyarakat dalam pengelolaan sampah masih dinilai lemah. Seharusnya dalam pengelolaan sampah, masyarakat juga dituntut kreatif dan inovatif dalam mengelola sampah. Masyarakat belum bisa mengelola sampah sesuai dengan prinsip 3R (Reduce, Reuse, dan Recylce) Masyarakat Kota Pontianak cenderung melakukaan paradigma lama dalam mengelola sampah. 3) Pengeloaan sampah pada tahap pewadahan, pemindahan dan pengumpulan hingga pada tempat pembuang akhir masih tergolong tidak memperhatikan kesehatan air udara hal ini dapat dilihat sering terjadi keterlambatan pengangkutan sampah dibeberapa komplek padat penduduk sehingga mencemari udara dan lingkungan.

Dari informasi diatas dapat diketahui bahwa pengelolaan sampah di Kota Pontianak masih belum memenuhi standar pengelolaan berwawasan lingkungan. Hal tersebut ditandai dengan masih adanya keterlambatan pengangkutan sampah oleh petugas kebersihan sehingga terjadi penumpukan sampah di komplekkomplek perumahan. Dampak dari penumpukan sampah tersebut mengakibatkan pencemaran udara, banyaknya lalat-lalat penyebaran kumankuman penyakit. Disamping itu pengelolaan ditempat pembuangan akhir (TPA) Batu Layang juga dinilai tidak memperhatikan

lingkungan. Penampungan air lindi sampah disinyalir mengaliri laut. Hal ini mengakibatkan pencemaran air laut dan dampak terhadap biota-biota yang ada diperairan laut. Pencemaran lingkungan akibat dari pengelolaan sampah yang tidak memenuhi standar yang telah ditetapkan dalam Undang-Undang Nomor 18 Tahun 2008 jelas-jelas sudah tidak masuk dalam katagori pengelolaan sampah yang berwawasan lingkungan.

\section{g. Inovasi pengelolaan sampah}

ANGKUTS atau singkatan dari angkut sampah hadir sebagai solusi atas permasalahan tersebut. Hafiz, pemuda Pontianak sang penggagas program mengungkapkan, ANGKUTS merupakan sebuah start up sociopreneur berbasis teknologi yang menyediakan solusi masalah sampah di Kota Pontianak dengan metode "dipilah, di Angkuts, 
dimanfaatkan." Hafiz juga menuturkan "ANGKUTS juga mengedukasi penduduk kota untuk menjadi bagian dari solusi masalah sampah dengan menjadi warga kota yang smart dalam mengelola sampah." Pernyataan tersebut disampaikan Hafiz seusai apel hari Peduli Sampah Nasional, Launching Gerakan Pungut Sampah dan Deklarasi Stop Buang Sampah Sembarangan di halaman Masjid Raya Mujahidin Pontianak, Minggu. Hafiz menegaskan, ANGKUTS merupakan solusi pintar untuk menangani masalah sampah di kota yang menjalankan program "smart city" seperti Pontianak. "ANGKUTS" membantu memecahkan masalah sampah dengan mengubah smapah dari 'dibuang' menjadi 'sumber daya' yang dimanfaatkan dan mendatangkan keuntungan melalui kerja sama seluruh warga Pontianak." Ungkapnya. Tujuan ANGKUTS selain ingin menjadi solusi masalah sampah, juga mendorong pertumbuhan ekonomi kota melalui kegiatan bisnis dan osial yang berkelanjutan dan berwawasan lingkungan. "ANGKUTS dengan pendekatan teknologi mencoba membantu masyarakat di Pontianak untuk memilah sampah agar sampah bisa dimanfaatkan terpisah," katanya. Melalui smartphone, warga dapat menghubungi tim ANGKUTS. Tim akan datang untuk mengumpulkan sampah seperti botol plastik, gelas air mineral, kertas HVS, koran dan kaleng alumunium untuk dibeli pihak ANGKUTS dan diolah.

Hafiz, yang juga Direktur PT. Angkuts Kreatif Indonesia mengatakan, kemudahan era digital harus ditangkap untuk mengatasi masalah sosial dan lingkungan. "Keuntungan yang didapat, jika menggunakan aplikasi ini, buang sampah malah dibayar. Tentu senilai sampah yang diserahkan kepada driver ANGKUTS, yang kita sebut PengAngkuts." jelasnya. Cara kerjanya, setelah mengunduh aplikasi tersebut, pengguna diberikan dua opsi: barang dan sampah. Setelah itu, pengguna bisa memilih kendaraan yang digunakan untuk mengangkut sampah atau barang dari rumahnya. Seluruh sampah akan ditimbang untuk menentukan uang yang akan diterima pengguna aplikasi. "Uang akan masuk dalam bentuk virtual account di akun bersangkutan.

\section{PEMBAHASAN}

Program penanganan sampah yang telah dijalankan di Kota Pontianak masih belum berjalan secara optimal dan belum memenuhi pengelolaan berwawasan lingkungan. Sehingga adapun rekomendasi dari pengelolaan sampah di Kota Pontianak adalah mengimplementasi dari program pemilahan sampah berbasis masyarakat dengan prinsip $3 \mathrm{R}$ dengan tujuan untuk mengurangi timbulan sampah guna meningkatkan kualitas lingkungan dengan upaya meningkatkan kesadaran warga dalam berperilaku hidup sehat.

Pokok persoalan yang akan disusun sebagai usulan pengelolaan sampah difokuskan pada peningkatkan peran dari pihak-pihak yang terlibat. Usulan tersebut terdiri dari tahap perencanaan, tahap implementasi, tahap pengendalian dan pengawasan serta tahap evaluasi.

1. Tahap Perencanaan

Pemerintah sebagai pihak pembuat kebijakan (regulator) berwenang membuat kebijakan tentang pengelolaan sampah. Sehingga pemerintah merupakan pihak yang paling tepat mengambil inisiatif agar program menjadi gerakan masyarakat. Dalam rangka pelibatan masyarakat dalam perencanaan, yang akan dilakukan adalah menjalin komunikasi dengan masyarakat melalui pengurus RT/RW. Pengurus RT/RW di sini adalah pihak yang memiliki kapabilitas sebagai fasilitator antara pemerintah dan masyarakat. Di tempat 
lain bisa jadi fasilitator tersebut adalah tokoh masyarakat, tokoh agama, LSM, akademisi atau pihak ketiga/swasta. Pokok terpenting mereka adalah pihak yang dipercaya oleh masyarakat dan pemerintah dan memiliki kemampuan sebagai fasilitator . hal utama yang harus disampaikan pertama kali dalam sosialisasi adalah tentang manfaat pengelolaan sampah. Untuk memperkuat penjelasan tentang manfaat pengelolaan sampah, pemerintah sebaiknya mengajak pengurus RT/RW untuk melakukan studi banding ke daerah yang telah berhasil melaksanakan pengelolaan sampah.

2. Tahap Implementasi

Dalam implementasi pemilahan sampah, pemerintah membrikan bantuan fasilitas termasuk biaya untuk pengelola karena biaya pengelolaan sampah merupakan kewajiban pemerintah (amanat UU RI No 18 Tahun 2008). Pemerintah mengatur dan memberikan insentif dan disinsentif. Walaupun masyarakat tidak keberatan dengan adanya retribusi sampah, namun alangkah baiknya jika pemerintah memberikan insentif pada masyarakat yang melakukan pemilahan sampah. Insentif diberikan untuk memotivasi masyarakat, agar masyarakat bersemangat melakukan pemilahan sampah. Insentif yang diberikan dapat dalam bentuk pengurangan retribusi bagi warga yang melakukan pemilahan sampah. Sedangkan bagi warga yang tidak melakukan pemilahan sampah, tetap membayar retribusi.

Ini sejalan dengan amanat UU No 18 Tahun 2008 Pasal 18. Pengelola menentukan mekanisme pengelolaan sampah, yang meliputi pengambilan sampah dari rumah-rumah dan pengangkutannya hingga ke TPPS. Pengelola bertanggungjawab mengelola sampah anorganik yang terkumpul, mulai dari pengumpulan, pengangkutan dan pemanfaatan/penjualannya, termasuk pemanfaatan uang hasil penjualan. Bersama dengan pengurus RT/RW, pengelola memberikan bimbingan kepada masyarakat agar mereka dapat mengelola sampahnya dengan benar. Termasuk di dalamnya memberikan bimbingan dalam pengelolaan sampah.

3. Tahap Evaluasi

Pemerintah melakukan evaluasi berdasarkan laporan yang diterima dari pengelola dan pengurus $\mathrm{RT} / \mathrm{RW}$, juga masukan dari masyarakat. Evaluasi dilakukan untuk menyempurnakan kebijakan yang sudah dibuat agar efektif dan efisien. Dalam kaitan dengan evaluasi, fungsi pengurus RT/RW adalah memberikan masukan kepada pemerintah dan pengelola.

Disamping itu juga menjaring masukan dari masyarakat. Pengelola menyampaikan laporan dan hasil evaluasi kepada pemerintah dan masyarakat. Penyampaian laporan dan evaluasi dilaksanakan secara bulanan dan tahunan. Hasil evaluasi ini untuk perbaikan pelaksanaan manajemen kedepan.

\section{SIMPULAN, IMPLIKASI, DAN KETERBATASAN}

\section{Simpulan}

Berdasarkan hasil pembahasan yang dihasilkan melalui wawancara dan observasi yang dilakukan penulis simpulkan Manajemen pengelolaan sampah Kota Pontianak dilihat dari aspek teknis operasional dan aspek non teknis. Aspek teknis operasional manajemen pengelolaan sampah Kota Pontianak masih menggunakan model pengelolaan paradigma lama pengelolaan sampah Kota Pontianak masih menggunakan model pengelolaan paradigma lama. Proses pengelolaan sampah dimulai dari pewadahan sampah-sampah dari sumbersumber sampah yang tersebar di Lingkungan Kota Pontianak. Selanjutnya sampah dikumpulkan oleh petugas 
kebersihan dan dipindahkan dari tempat pemungutan sampah sementara kemudian dilakukan pengangkutan ke tempat pembuangan akhir (TPA). Harusnya model pengelolaan manajemen pengelolaan sampah harus sesuai dengan yang di amanatkan dalam UU Nomor 18 tahun 2008.

Aspek non teknis manajamen pengelolaan sampah masih belum optimal hal ini belum terlaksananya Penerapan teknologi yang tepat guna Peran serta masyarakat dalam pengelolaan sampah masih belum optimalnya keuntungan dalam pengelolaan sampah, Optimalisasi TPA sampah yang merusak lingkungan baik air dan udara dan Sistem kelembagaan pengelolaan sampah yang belum terintegrasi sehingga pengelolaan sampah di Kota Pontianak belum sepenuh berwawasan lingkungan.

ANGKUTS atau singkatan dari angkut sampah merupakan inovasi pengelolaan sampah yang berbasis aplikasi hadir sebagai solusi atas permasalahan tersebut. Hafiz, pemuda Pontianak sang penggagas program mengungkapkan, ANGKUTS merupakan sebuah start up sociopreneur berbasis teknologi yang menyediakan solusi masalah sampah di Kota Pontianak dengan metode "dipilah, di Angkuts.

\section{Implikasi dan Keterbatasan}

Dalam perencanaan pengelolaan sampah, Undang-Undang Pengelolaan Sampah mengharapkan pemerintah kota/kabupaten dapat membentuk semacam forum pengelolaan sampah skala kota/kabupaten atau provinsi. Forum ini beranggotakan masyarakat secara umum, perguruan tinggi, tokoh masyarakat, organisasi lingkungan/persampahan, pakar, badan usaha dan lainnya.

Hal-hal yang dapat difasilitasi forum adalah: memberikan usul, pertimbangan dan saran terhadap kinerja pengelolaaan sampah, membantu merumuskan kebijakan pengelolaan sampah, memberikan saran dan dapat dalam penyelesaian sengketa persampahan. Sampai saat ini, belum ada kebijakan nasional mengenal persampahan itu sendiri masih bersifat sosialisasi. Melihat di perkotaan penanganan pengelolaan sampah sudah sangat mendesak, diharapkan UU No. 18 Tahun 2008 tentang Pengelolaan Sampah dapat diimplementasikan.

Keberadaan informan yang tidak selalu ada di tempat menjadi salah satu faktor yang di alami peneliti dalam melaksanakan penelitian ini. Akan tetapi secara umum apa yang dilakukan dalam pelaksanaan penelitian ini dapat tergambar dari hasil wawancara yang dilakukan kepada informan.

\section{REFERENSI}

\section{Sumber Jurnal/Prosiding}

Dompak, Ul Qadri. 2015. Waste Management Environmental in Batam City. Proceedings Book

Prasetyo, H., Indriani, I., \& Widodo, A. (2020). Comparative study on the application of green accounting based on university social responsibility at Universities in Pontianak. Journal of Islamic Accounting and Finance Research, 2(2), 185-208. doi:http://dx.doi.org/10.21580/jiafr. $\underline{\text { 2020.2.2.6316 }}$

\section{Sumber Buku}

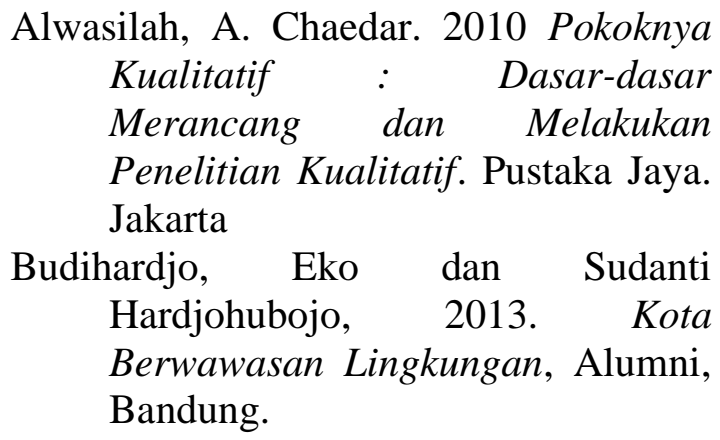


Sudradjat, 20016. Mengelola Sampah Kota, Penebar Swadaya Cetakan I Jakarta.

Terry, G.R. dan L.W. Rue, 1991. DasarDasar Manajemen, Bumi Aksara, Jakarta.

Towow, 2003. Pengelolaan Sampah Terpadu Sebagai Salah Satu Upaya Mengatasi Problem Sampah Di Perkotaan, Jakarta

\section{Sumber Peraturan Perundang- undangan}

Kementerian Lingkungan Hidup Republik Indonesia, 2008. Kota Ekologis.

Kementerian Lingkungan Hidup, 2010. Konsep Dasar Pengelolaan Sampah- dalam RUU Tentang Pengelolaan Sampah, Jakarta.

Kementerian Lingkungan Hidup, 2007. Pengelolaan Sampah Perkotaan di Indonesia,

Kementerian Lingkungan Hidup, 2007. Rancangan Undang-Undang Republik Indonesia tentang Pengelolaan Sampah, Jakarta.

Kementerian Lingkungan Hidup, 2008. Undang-Undang Pengelolaan Persampahan, Jakarta.

Kementerian Lingkungan Hidup, 2007.

Buku Pedoman Implementasi 3R Skala Kota-Final Draf, Jakarta.

Proyek Pengelolaan Lingkugan Jawa Bagian Barat (WJEMP), Rencana Pengelolaan Persampahan Kota Depok, Waste Management Corporation (JWMC) Consultant Support 20 Januari 2006.

\section{Sumber Rujukan Tesis}

Nirawandi, Iwan, 2008. Analisis Kebijakan Pengelolaan Sampah Kota Bogor, Tesis Program Magister Perencanaan dan Kebijakan Publik, Fakultas Ekonomi Universitas Indonesia, Tidak dipublikasikan.
Rahman, 2014. Analisis Nilai Ekonomi Pengelolaan Sampah di Kota Medan, Tesis Program Pascasarjana Universitas Universitas Sumatera Utara Medan, Tidak dipublikasikan. 